\title{
Sistem Pendukung Keputusan dengan Metode AHP untuk Penilaian Kompetensi Soft Skill Karyawan
}

\author{
Rusydi Umar*, Abdul Fadlil, Yuminah \\ Program studi Magister Tekik Informatika \\ Universitas Ahmad Dahlan, Yogyakarta \\ Yogyakarta 55164 \\ *rusydi_umar@rocketmail.com
}

\begin{abstract}
Abstrak-Karyawan dalam perusahaan merupakan sumber daya utama yang dituntut untuk mampu memberikan pelayanan terbaik dan kinerja yang optimal. Soft skill karyawan adalah keterampilan individu karyawan yang dapat menunjang hubungan individu karyawan dengan karyawan lain, meningkatkan kinerja dan membuka prospek kariernya. Penilaian kinerja karyawan yang dilaksanakan oleh perusahaan umumnya hanya untuk penilaian prestasi kerja yakni bagaimana pekerjaan dapat dikerjakan dengan baik, mencapai target yang ditetapkan dan meraih tujuan akhir yang diinginkan (hard skill). Penilaian terkait kemampuan soft skill karyawan belum banyak dilakukan. Ada beberapa kriteria yang diterapkan beberapa perusahaan dalam melakukan penilaian kompetensi soft skill, tetapi kriterianya masih berbeda-beda. Penelitian ini membahas penilaian kompetensi soft skill karyawan dengan menerapkan empat kriteria. Keempat kriteria ini adalah kemampuan komunikasi, kemampuan bekerja sama, kejujuran, dan kemampuan interpersonal. Analisis data menerapkan metode Analytical Hierarchical Process (AHP), yang memungkinkan perhitungan matematis dengan berbagai kriteria. Hasil penelitian menunjukkan nilai rasio konsistensi 0.053 yang berarti kurang dari nilai rasio konsistensi yang digunakan dalam metode AHP yaitu 0.1, sehingga hasil perhitungan tersebut valid, dan dapat digunakan. Penelitian ini menghasilkan penilaian prioritas kompetensi soft skill yang dibutuhkan perusahaan sebagai berikut: Komunikasi 48\%, Kerja sama 27\%, Kejujuran 16\%, dan interpersonal 10\%. Hasil penelitian ini membuktikan bahwa metode AHP dapat digunakan pada penilaian kompetensi soft skill karyawan.
\end{abstract}

Kata Kunci: analytical hierarchical process; sistem pendukung keputusan; penilaian kompetensi; soft skill

\section{Pendahuluan}

Mencapai pengembangan karier terbaik merupakan satu harapan besar bagi seseorang, karena akan memiliki implikasi luas pada kesejahteraan hidup. Kenyataan di lapangan menunjukkan bahwa soft skill memiliki peranan yang menentukan keberhasilan karyawan dalam pengembangan dirinya untuk mencapai kesuksesan. Hard skill memiliki peranan sebagai prasyarat minimal untuk karyawan dalam memasuki dunia kerja. Kompetensi hard skill adalah kompetensi yang berkaitan dengan kemampuan menyerap ilmu pengetahuan atau keahlian dan merupakan kemampuan untuk melakukan tugas atau kegiatan tertentu. Soft skill berkaitan dengan kemampuan karyawan dalan berinteraksi dengan sesama karyawan baik dalam pekerjaan maupun di luar pekerjaan

Soft skill dalam dunia kerja dapat menjadi penunjang kompetensi teknis atau hard skill. Karyawan yang mempunyai kompetensi teknis dan keahlian profesi yang baik tetapi tidak mempunyai kompetensi soft skill yang baik maka dapat menghambat kinerja karyawan tersebut. Kompetensikompetensi soft skill yang dibutuhkan di dunia kerja sudah teridentifikasi dengan jelas. Rilman dkk. [1] menyebutkan bahwa soft skill yang seharusnya dimiliki karyawan adalah kemampuan komunikasi, kemampuan menyelesaiakan masalah, kemampuan dalam tim, kemampuaan belajar sepanjang hayat, kemampuan mengelola informasi, kemampuan wirausaha, kemampuan beretika, moral dan professional, dan kemampuan kepemimpinan.

\begin{tabular}{lll}
\hline No. & Kemampuan/keterampilan & Skor Kepentingan \\
\hline 1. & Kemampuan Komunikasi & 4,69 \\
2. & Kejujuran/Integritas & 4,59 \\
3. & Kemampuan Bekerja Sama & 4,54 \\
4. & Kemampuan Interpersonal & 4,50 \\
5. & Beretika & 4,46 \\
6. & Motivasi/Inisiatif & 4,42 \\
7. & Kemampuan Beradaptasi & 4,41 \\
8. & Daya Analitik & 4,36 \\
9. & Kemampuan Komputer & 4,21 \\
10. & Kemampuan Berorganisasi & 4,05 \\
11. & Berorientasi pada Detail & 4,00 \\
12. & Kepemimpinan & 3,97 \\
13. & Kepercayaan Diri & 3,95 \\
14. & Ramah & 3,85 \\
\hline \multicolumn{2}{l}{ Sumber. Hasil Survei NACE USA (2002). }
\end{tabular}

Gambar 1. Kompetensi Soft Skill yang diperlukan dunia kerja. Sumber Hasil Survei NACE USA [1]

Kemampuan-kemampuan tersebut, untuk lebih jelas dapat dilihat dalam gambar 1.

Perusahaan dalam kurun waktu tertentu selalu melakukan penilaian kinerja karyawannya. Penilaian yang dilakukan setiap perusahaan mengikuti kebijakan yang berbeda-beda. Penilaian kinerja karyawan tersebut sebagai bentuk penilaian kerja nyata atas standar kualitas maupun kuantitas yang dihasilkan oleh karyawan. Penilaian prestasi kerja penting bagi setiap karyawan maupun perusahaan untuk mengambil keputusan dan menentukan kebijaksanaan selanjutnya. Kegagalan perusahaan dalam 
menilai kinerja karyawan dapat mengakibatkan kegagalan perusahan dalam mencapai target umum perusahaan dan dapat menurunkan motivasi karyawan dalam berprestasi.

Sistem Pendukung Keputusan (SPK) merupakan sistem yang dapat memberikan pemecahan masalah, melakukan komunikasi untuk pemecahan masalah tertentu dengan terstruktur maupun tidak terstruktur. SPK didesain untuk dapat digunakan dan dioperasikan dengan mudah oleh orang yang hanya memiliki kemampuan dasar pengoperasian komputer. SPK dibuat dengan menerapkan adaptasi kompetensi yang tinggi sehingga dapat dijadikan sebagai alternatif dalam pengambilan sebuah keputussan [2]. SPK terdiri atas dua kata kunci, yaitu sistem informasi dan keputusan. Sistem informasi merupakan serangkaian prosedur formal dengan tahapan di mana data dikelompokkan, diproses sehingga menghasilkan informasi yang selanjutnya diberikan kepada pengguna. Keputusan adalah serangkaian kegiatan untuk memilih suatu tindakan dalam memecahkan masalah. Tindakan memilih dari alternatif yang dihadapi yang didasarkan pada fakta dan dilakukan melalui pendekatan sisematis yang dapat memberikan solusi terbaik yang dilakukan oleh manajer disebut pengambilan keputusan [3].

Penelitian terkait SPK telah banyak dilakukan. Palasara meneliti pengambilan keputusan untuk menilai karyawan terbaik dengan kriteria antara lain kuantitas kerja, kualitas kerja, kejujuran, tanggung jawab, motivasi diri, dedikasi, penampilan, keterampilan kerja, inisiatif, pemanfaatan waktu, kerja sama, komunikasi, dan disiplin [4]. Penelitian ini menghasilkan nilai indeks konsistensi sebesar 0.01 artinya nilai kesalahan di bawah $10 \%$, dan membuktikan bahwa metode AHP cocok digunakan untuk pemilihan karyawan terbaik.

Purnomo, dkk. membandingkan metode AHP, TOPSIS, dan AHP-TOPSIS dalam memutuskan penerima beasiswa [5]. Merekam menguji 4 kriteria yang meliputi nilai UASBN, nilai TPA, nilai IQ, dan nilai piagam. Penelitian tersebut menghasilkan bahwa metode TOPSIS menjadi metode terbaik.

Permana menerapkan SPK untuk memilih sekolah menengah kejuruan favorit dengan menggunakan kriteria fasilitas, biaya, kualitas, dan SDM Siswa [6]. Mereka menggunakan metode multi criteria decision dan menghasilkan bahwa teknik komputer dan jaringan adalah jurusan yang terfavorit di SMK.

Penelitian lain terkait sistem pendukung keputusan adalah [7] yang mencermati sebuah rancangan analisis sistem untuk penilaian soft skill siswa SMK sebagai calon tenaga kerja. Penelitian [8] menerapkan sistem pendukung keputusan untuk memprediksi stok barang. Sementara itu penelitian [9] menggunakan SPK untuk pemilihan rumah tinggal dan penelitian [10] menerapkan sistem pakar untuk melakukan diagnosis gangguan layanan telekomunikasi pada sebuah operator telekomunikasi Indonesia. Sedangkan penelitian [11] menghasilkan sistem untuk menangani tambahan belajar mengajar peminatan sesuai dengan kegitan pembelajaran yang dibutuhkan.

Penelitian ini mengkaji tentang penilaian kompetensi soft skill karyawan dengan metode AHP, sedangkan pada penelitian yang dilaporkan di atas banyak mengkaji penilaian karyawan terbaik pada kompetensi hard skill saja. Berdasarkan 14 kebutuhan kompetensi soft skill yang banyak dibutuhkan oleh dunia kerja, maka penelitian ini mengambil 4 kriteria teratas yaitu: kemampuan komunikasi, kemampuan bekerja sama, kejujuran, dan interpersonal. Kenyataan di lapangan bahwa 4 kompetensi tersebut memang sangat menentukan kesuksesan karyawan dalam bekerja. Empat kompetensi tersebut saling terkait antara satu dengan yang lain, misalnya jika seorang karyawan mempunyai kemampuan komunikasi yang baik, maka karyawan tersebut mempunyai tingkat kejujuran yang baik, dari kejujuran yang baik maka akan dapat bekerja sama dalam tim dengan baik, dengan demikian karyawan tersebut mempunyai kemampuan interpersonal yang baik [12]. Kompetensi soft skill mempunyai peran yang amat sangat penting, karena menyangkut kemampuan dasar (basic skill) seseorang dalam menyelesaikan suatu pekerjaan [13].

Sebagai bentuk usaha untuk mendorong kinerja persusahaan, semakin banyak perusahaan yang melakukan penilaian kinerja karyawan menitikberatkan pada kemampuan soft skill, maka akan memberikan kontribusi nyata terhadap pembentukan karakter kehidupan bangsa. Dengan demikian kemampuan soft skill sangat menentukan kemajuan diri dan dapat terwujud dengan melakukan pembiasaan di kehidupan sehari-hari. Sekarang bekerja juga harus memperhatikan pengembangan soft skill (interaksi sosial) sebab hal ini sangat penting dalam pembentukan karakter karyawan sehingga mampu bersaing, beretika, bermoral, sopan santun, dan berinteraksi dengan masyarakat. Sehingga terbentuklah karaker yang baik. Karakter yang baik akan berimbas pada kinerja yang baik dan terbentuklah karyawan yang baik. Sudah saatnyalah perusahaan-perusahaan melakukan penilaian kinerja karyawan dari segi kemampuan soft skill yang dimiliki.

\section{Dasar Teori}

Analytical Hierarchical Process (AHP) merupakan hierarki dengan imput atau masukan utama berupa pandangan manusia. Dikembangkan oleh Prof. Thomas Lorie Saaty dari Wharton Business School awal tahun 1970. Metode ini gunakan untuk mencari urutan atau ranking prioritas dari berbagai alternatif dalam pemecahan masalah [14]. AHP banyak digunakan untuk mengekspresikan pengambilan suatu keputusan yang sangat efektif dari suatu permasalahan yang komplek.

Penentuan prioritas dengan metode AHP dilakukan melalui beberapa tahapan yaitu:

a. Menyusun hierarki.

b. Menilai kriteria dan alternatif.

c. Memilih prioritas.

d. Menentukan nilai konsistensi logis.

Di dalam mengambil keputusan, penting untuk diketahui baik tidaknya nilai konsistensi yang digunakan. Adapun langkah-langkah yang harus dilakukan adalah:

1) Menghitung nilai perbandingan yang sudah ditetapkan dengan membagi nilai skala yang ada di setiap sel dibagi dengan nilai sel prioritas.

2) Hasil pehitungan dari langkal no. 1 di masingmasing sel dibagi dengan jumlah total di masingmasing kolom.

3) Mencari Eigen dengan cara menghitung ratarata per baris. 
4) Mencari Lamda ( $\lambda$ ) dengan cara mengalikan masing-masing nilai eigen per baris dengan jumlah total per kolom.

5) Mencari lamda ( $\lambda$ maks) dengan cara menjumlahkan hasil lamda

e. Menentukan nilai indeks konsistensi (CI)

Rumus yang digunakan sebagai berikut:

$$
C I=\frac{\lambda \max -n}{n-1}
$$

Keterangan:

$\mathrm{n}=$ banyaknya kreteria.

f. Menetukan rasio konsistensi (CR)

Rumus yang digunakan sebagai berikut:

$$
C R=\frac{C I}{R I}
$$

Keterangan:

$\mathrm{CR}=$ Rasio Konsistensi

$\mathrm{CI}=$ Indeks Konsistensi

RI = Indeks Random Konsistensi

g. Memeriksa konsistensi hierarki.

Jika hasil perhitungan nilai rasio konsistensi lebih dari $10 \%$, maka harus diperbaiki atau dihitung ulang. Tapi jika rasio konsistensi kurang atau sama dengan 0,1 maka dapat dinyatakan benar nilai perhitungannya. Nilai RI atau index random seperti terlihat pada tabel 1.

\section{Metode}

\section{a. Pengumpulan Data}

Metode deskriptif analitik yang akan digunakan dalam penelitian ini dengan menyajikan hasil survey yang berupa kuesioner. Data sekunder diambil melalui berbagai media, seperti: internet, buku literatur dan jurnal serta artikel-artikel sehingga didapatkan informasi yang akurat mengenai penilaian kompetensi soft skill. Selanjutnya data diolah dengan menggunakan pendekatan proses hierarki analitis (AHP) untuk menentukan kriteria kompetensi soft skill yang akan digunakan.

\section{b. Tahap Penelitian}

Tahapan penelitian dalam penelitian ini adalah dimulai dengan menetukan masalah, pemilihan kriteria, komputasi AHP, perhitungan analisis data, kesimpulan (lihat gambar 2).

c. Menentukan Masalah dan Pemilihan Kriteria

Sasaran yang ingin dicapai dalam penelitian ini adalah mendapatkan cara penilaian kompetensi soft skill. Kriteria penilaian dipilih dan diuji menggunakan metode AHP sesuai dengan kebutuhan dunia kerja seperti terlihat pada Tabel 2.

Kriteria-kriteria pada Tabel 2 dimasukkan ke dalam tabel perbandingan dua kriteria berpasangan seperti terlihat pada tabel 3 .

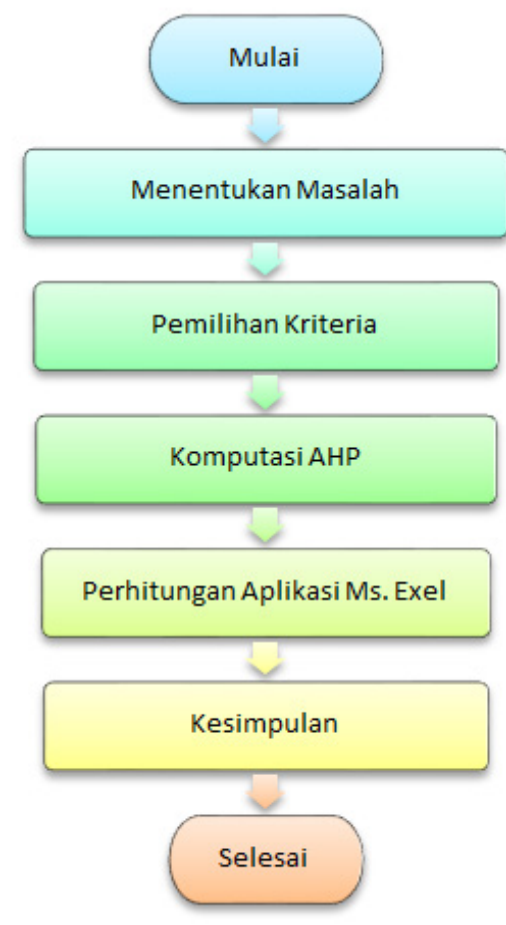

Gambar 2. Tahap-tahap penelitian

Tabel 1. Nilai Indeks Random

\begin{tabular}{ccccccccccc}
\hline $\mathbf{N}$ & $\mathbf{1}$ & $\mathbf{2}$ & $\mathbf{3}$ & $\mathbf{4}$ & $\mathbf{5}$ & $\mathbf{6}$ & $\mathbf{7}$ & $\mathbf{8}$ & $\mathbf{9}$ & $\mathbf{1 0}$ \\
\hline $\mathrm{RI}$ & 0 & 0 & 0.58 & 0.90 & 1.12 & 1.24 & 1.32 & 1.41 & 1.45 & 1.49 \\
\hline
\end{tabular}

Tabel 2. Sasaran dan Kriteria

\begin{tabular}{ll}
\hline \multicolumn{1}{c}{ Sasaran } & \multicolumn{1}{c}{ Kriteria } \\
\hline \multirow{2}{*}{ Penilaian } & Kemampuan Komunikasi \\
Kompetensi soft & Kejujuran \\
skill Karyawan & Kemampuan Bekerjasama \\
& Kemampuan Interpersonal \\
\hline
\end{tabular}

Tabel 3. Perbandingan Antar 2 Kriteria

\begin{tabular}{llll}
\hline \multicolumn{1}{c}{ Kriteria } & & Perbandingan & \multicolumn{1}{c}{ Kriteria } \\
\hline Komunikasi & 2 & & Interpersonal \\
Kerja sama & 3 & Kejujuran \\
Kejujuran & 4 & Kerjasama \\
Interpersonal & 5 & Komunikasi \\
\hline
\end{tabular}

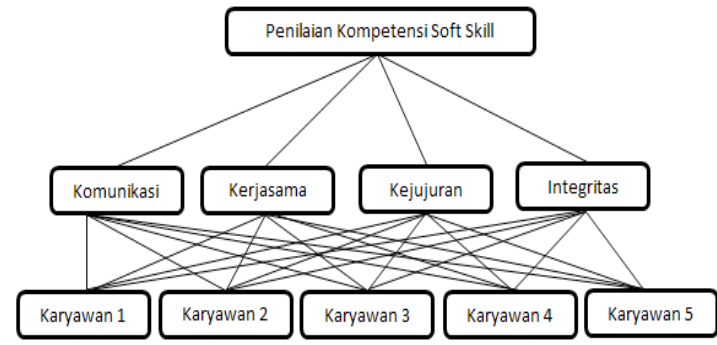

Gambar 3. Hierarkhi metode AHP penilaian soft skill 
Tabel 4. Kriteria dalam Skala Penilaian Soft Skill

\begin{tabular}{lcccc}
\hline \multicolumn{1}{c}{ Kriteria } & Komunikasi & Kerjasama & Kejujuran & Interpesonal \\
\hline Komunikasi & 1 & 2 & 3 & 5 \\
Kerjasama & 0.50 & 1 & 1.50 & 4 \\
Kejujuran & 0.33 & 0.67 & 1 & 1.67 \\
Interpesonal & 0.2 & 0.4 & 0.6 & 1 \\
Jumlah & 2.03 & 4.07 & 6.1 & 11.67 \\
\hline
\end{tabular}

Tabel 5. Hasil perhitungan Lamda maks Penilaian Soft Skill

\begin{tabular}{|c|c|c|c|c|c|c|c|}
\hline Kriteria & Komunikasi & Kerjasama & Kejujuran & Interpesonal & EIGIN & $\lambda$ (lamda) & $\lambda$ maks \\
\hline komunikasi & 0.491803279 & 0.49180328 & 0.49 & 0.428571429 & 0.475995316 & 0.9678571 & 4.144941452 \\
\hline kerjasama & 0.245901639 & 0.24590164 & 0.25 & 0.342857143 & 0.270140515 & 1.0985714 & \\
\hline kejujuran & 0.163934426 & 0.16393443 & 0.16 & 0.142857143 & 0.158665105 & 0.9678571 & \\
\hline interpesonal & 0.098360656 & 0.09836066 & 0.10 & 0.085714286 & 0.095199063 & 1.1106557 & \\
\hline
\end{tabular}

Tabel 3 menunjukkan bahwa kemampuan komunikasi dan kemampuan interpersonal memiliki perbandingan dengan skala 2, yang berarti nilai keduanya sama atau setara. Kemampuan kerja sama dengan kejujuran berada pada skala 3 yang berarti kemampuan kerja sama sedikit lebih penting daripada kejujuran. Perbandingan antara kejujuran dengaan kemampuan kerja sama berada pada skala 4 berarti nilai di antara keduanya sama. Kemampuan interpersonal dengan komunikasi berada pada skala 5 yang berarti kemampuan interpersonal lebih penting daripada komunikasi.

\section{d. Komputasi AHP}

Komputasi AHP dilakukan melalui tahapan-tahapan sebagai berikut.

a. Menyusun hierarki penialaian soft skill

Gambar 3 memperlihatkan hierarki penilaian soft skill yang menunjukkan bahwa posisi tingkat 1 adalah sasaran. Sasaran yang dimaksud adalah Penilaian soft skill karyawan. Posisi tingkat 2 adalah kriteria yang meliputi komunikasi, kerja sama, kejujuran, dan interpersonal. Sedangkan posisi tingkat 3 adalah sebagai alternatif yaitu karyawan yang dinilai.

b. Penilaian kriteria dan menentukan prioritas Kriteria dan skala penilaian yang digunakan seperti terlihat pada tabel 4 .

Tabel 5 merupakan tabel perbandingan dengan masing-masing kriteria berdasarkan skala yang sudah ditetapkan pada tabel 4, sebagai contoh komunikasi dibandingkan dengan komunikasi akan menghasilkan nilai 0 maksudnya $1 / 1=0$, komunikasi dibandingkan dengan kerjasama akan menghasilkan 0.50 maksudnya $1 / 2=0.50$, dilanjutkan perbandingan hingga semua kreteria.

c. Konsistensi Logis

Dalam menentukan nilai konsistensi dilakukan dengan langkah-langkah sesuai pada metode AHP, dan diperolah hasil seperti terlihat pada tabel 5

Tabel 6 memperlihathan hasil perhitungan:

Eigen $=0.491+0,491+0.49+0.428=0.475$ $\lambda$ (lamda) $=0.475 \times 2.03=0.967$

$\lambda$ maks $=0.967+1.098+0.967+1.110=4.144$

sehingga penghitungan Consistency Index (CI) sebagai berikut:

$$
\begin{aligned}
C I & =\frac{\lambda \max -n}{n-1} \\
& =\frac{4144941452-4}{4-1} \\
& =0.048313817
\end{aligned}
$$

Dan penghitungan Rasio Konsistensi/Consistency Ratio (CR) sebagai berikut:

$$
\begin{aligned}
C R & =\frac{C I}{R I} \\
& =\frac{0.48313817}{0.9} \\
& =0.053682019
\end{aligned}
$$

d. Memeriksa konsistensi hierarki

Jika nilainya Rasio Konsistensi lebih dari 10\%, maka penilaian data judgment harus diperbaiki. Namun jika Rasio Konsistensi (CI/CR) kurang atau sama dengan 0,1 maka benar. Dari hasil perhitungan diperoleh nilai Rasio Konsistensi 0.053682019 adalah kurang dari atau sama dengan 0.1 maka hasil perhitungan bisa dinyatakan benar. Sehingga diperoleh prioritas kompetensi soft skill yang dibutuhkan perusahaan sebagai berikut; komunikasi $48 \%$, kerja sama 27\%, kejujuran 16 $\%$, dan interpersonal $10 \%$.

\section{Hasil}

Perhitungan dilakukan pada program aplikasi pengolah angka Microsoft Excel 2010, sampai menghasilkan prioritas penilaian kompetensi soft skill karyawan. Hasil yang diperoleh dari penelitian yang dilakukan dapat disajikan sebagai berikut: 
Tabel 6. Hasil Uji Validitas Kompetensi Komunikasi

\begin{tabular}{lcccccc}
\hline \multirow{2}{*}{ NAMA } & \multicolumn{6}{c}{ KRITERIA KOMUNIKASI } \\
\cline { 2 - 7 } & K1 & K2 & K3 & K4 & K5 & K6 \\
\hline rxy & 0.252 & 0.857 & 0.662 & 0.85 & 0.894 & 0.837 \\
r-hitung & 0.712 & 2.424 & 1.873 & 2.405 & 2.528 & 2.368 \\
r-tabel & 0.632 & 0.632 & 0.632 & 0.632 & 0.632 & 0.632 \\
signifikansi validitas & valid & valid & valid & valid & valid & valid \\
\hline
\end{tabular}

Tabel 7. Hasil Uji Validitas Kompetensi Kerja Sama

\begin{tabular}{lccccccc}
\hline \multirow{2}{*}{ Nama } & \multicolumn{7}{c}{ Kriteria Kerjasama } \\
\cline { 2 - 8 } & B1 & B2 & B3 & B4 & B5 & B6 & B7 \\
\hline rxy & 0.537 & 0.879 & 0.836 & 0.792 & 0.885 & 0.508 & 0.883 \\
r-hitung & 1.52 & 2.485 & 2.363 & 2.241 & 2.504 & 1.437 & 2.496 \\
r-tabel & 0.632 & 0.632 & 0.632 & 0.632 & 0.632 & 0.632 & 0.632 \\
signifikansi validitas & valid & valid & valid & valid & valid & valid & valid \\
\hline
\end{tabular}

Tabel 8. Hasil Uji Validitas Kompetensi Kerja Sama

\begin{tabular}{lcccccc}
\hline \multirow{2}{*}{ Nama } & \multicolumn{7}{c}{ Kriteria Kejujuran } \\
\cline { 2 - 7 } & J1 & J2 & J3 & J4 & J5 & J6 \\
\hline rxy & 0.553 & 0.616 & 0.853 & 0.828 & 0.853 & 0.754 \\
r-hitung & 1.565 & 1.743 & 2.412 & 2.341 & 2.412 & 2.134 \\
r-tabel & 0.632 & 0.632 & 0.632 & 0.632 & 0.632 & 0.632 \\
signifikansi validitas & valid & valid & valid & valid & valid & valid \\
\hline
\end{tabular}

Tabel 9. Hasil Uji Validitas Kompetensi Interpersonal

\begin{tabular}{lcccccccc}
\hline \multirow{2}{*}{ Nama } & \multicolumn{7}{c}{ Kriteria Interpersonal } \\
\cline { 2 - 9 } & I1 & I2 & I3 & I4 & I5 & I6 & I7 & I8 \\
\hline rxy & 0.539 & 0.563 & 0.613 & 0.757 & 0.83 & 0.623 & 0.363 & 0.53 \\
r-hitung & 1.524 & 1.594 & 1.734 & 2.142 & 2.346 & 1.763 & 1.026 & 1.499 \\
r-tabel & 0.632 & 0.632 & 0.632 & 0.632 & 0.632 & 0.632 & 0.632 & 0.632 \\
signifikansi validitas & valid & valid & valid & valid & valid & valid & \multirow{2}{*}{ valid } & valid \\
\hline
\end{tabular}

Tabel 10. Nilai Reliabilitas Alpha Cronbach's

\begin{tabular}{lcc}
\hline Kriteria & Alpha Cronbach's & keterangan \\
\hline Komunikasi & 0.798 & Reliabel \\
Kerja sama & 0.987 & Reliabel \\
Kejujuran & 0.836 & Reliabel \\
interpersonal & 0.604 & Reliabel \\
\hline
\end{tabular}

Tabel 11. Hasil Rekap Kuisioner Karyawan

\begin{tabular}{ccccc}
\hline Karyawan & komunikasi & kerjasama & kejujuran & interpersonal \\
\hline K1 & 18 & 23 & 21 & 26 \\
K2 & 24 & 20 & 30 & 36 \\
K3 & 21 & 25 & 24 & 26 \\
K4 & 18 & 24 & 22 & 28 \\
K5 & 22 & 26 & 30 & 33 \\
K6 & 27 & 30 & 24 & 33 \\
K7 & 20 & 22 & 24 & 28 \\
K8 & 27 & 32 & 30 & 35 \\
K9 & 22 & 26 & 27 & 29 \\
K10 & 26 & 32 & 25 & 32 \\
\hline
\end{tabular}


Tabel 12. Contoh Perhitungan Matriks Perbandingan pada Kriteria Kamunikasi

\begin{tabular}{|c|c|c|c|c|c|c|c|c|c|c|c|}
\hline Karyawan & K1 & $\mathrm{K} 2$ & K3 & K4 & K5 & K6 & K7 & K8 & K9 & K10 & \\
\hline K1 & 1 & 0.75 & 0.8571429 & 1 & 0.818181818 & 0.66666667 & 0.9 & 0.666666667 & 0.818182 & 0.692307692 & \\
\hline $\mathrm{K} 2$ & 1.333333333 & 1 & 1.1428571 & 1.333333333 & 1.090909091 & 0.8888889 & 1.2 & 0.888888889 & 1.090909 & 0.923076923 & \\
\hline $\mathrm{K} 3$ & 1.166666667 & 0.875 & 1 & 1.166666667 & 0.954545455 & 0.7777778 & 1.05 & 0.777777778 & 0.954545 & 0.807692308 & \\
\hline K4 & 1 & 0.75 & 0.8571429 & 1 & 0.818181818 & 0.6666667 & 0.9 & 0.666666667 & 0.818182 & 0.692307692 & \\
\hline K5 & 1.222222222 & 0.916666667 & 1.047619 & 1.222222222 & 1 & 0.8148148 & 1.1 & 0.814814815 & 1 & 0.846153846 & \\
\hline K6 & 1.5 & 1.125 & 1.2857143 & 1.5 & 1.227272727 & 1 & 1.35 & 1 & 1.227273 & 1.038461538 & \\
\hline K7 & 1.111111111 & 0.83333333 & 0.952381 & 1.111111111 & 0.909090909 & 0.7407407 & 1 & 0.740740741 & 0.909091 & 0.769230769 & \\
\hline K8 & 1.5 & 1.125 & 1.2857143 & 1.5 & 1.227272727 & 1 & 1.35 & 1 & 1.227273 & 1.038461538 & \\
\hline K9 & 1.222222222 & 0.916666667 & 1.047619 & 1.222222222 & 1 & 0.8148148 & 1.1 & 0.814814815 & 1 & 0.846153846 & \\
\hline $\mathrm{K} 10$ & 1.444444444 & 1.08333333 & 1.2380952 & 1.444444444 & 1.181818182 & 0.962963 & 1.3 & 0.962962963 & 1.181818 & 1 & \\
\hline Jumlah & 12.50 & 9.38 & 10.71 & 12.50 & 10.23 & 8.33 & 11.25 & 8.33 & 10.23 & 8.65 & \\
\hline Karyawan & K1 & $\mathrm{K} 2$ & $\mathrm{~K} 3$ & K4 & K5 & K6 & K7 & K8 & K9 & K10 & EIGEN \\
\hline K1 & 0.08 & 0.08 & 0.08 & 0.08 & 0.08 & 0.08 & 0.08 & 0.08 & 0.080 & 0.080 & 0.08000 \\
\hline $\mathrm{K} 2$ & 0.106666667 & 0.11 & 0.1066667 & 0.106666667 & 0.106666667 & 0.1066667 & 0.11 & 0.11 & 0.107 & 0.107 & 0.10667 \\
\hline $\mathrm{K} 3$ & 0.093333333 & 0.09 & 0.0933333 & 0.093333333 & 0.093333333 & 0.0933333 & 0.09 & 0.09 & 0.093 & 0.093 & 0.09333 \\
\hline K4 & 0.08 & 0.08 & 0.08 & 0.08 & 0.08 & 0.08 & 0.08 & 0.08 & 0.080 & 0.080 & 0.08000 \\
\hline K5 & 0.097777778 & 0.10 & 0.0977778 & 0.097777778 & 0.097777778 & 0.0977778 & 0.10 & 0.10 & 0.098 & 0.098 & 0.09778 \\
\hline K6 & 0.12 & 0.12 & 0.12 & 0.12 & 0.12 & 0.12 & 0.12 & 0.12 & 0.120 & 0.120 & 0.12000 \\
\hline $\mathrm{K} 7$ & 0.088888889 & 0.09 & 0.0888889 & 0.088888889 & 0.088888889 & 0.0888889 & 0.09 & 0.09 & 0.089 & 0.089 & 0.08889 \\
\hline K8 & 0.12 & 0.12 & 0.12 & 0.12 & 0.12 & 0.12 & 0.12 & 0.12 & 0.120 & 0.120 & 0.12000 \\
\hline K9 & 0.097777778 & 0.10 & 0.0977778 & 0.097777778 & 0.097777778 & 0.0977778 & 0.10 & 0.10 & 0.098 & 0.098 & 0.09778 \\
\hline K10 & 0.115555556 & 0.12 & 0.1155556 & 0.115555556 & 0.115555556 & 0.1155556 & 0.12 & 0.12 & 0.116 & 0.116 & 0.11556 \\
\hline
\end{tabular}

Tabel 13. Nilai Matriks Perbandingan untuk semua kriteria dan eigen prioritas perusahaan.

\begin{tabular}{cccccc}
\hline Karyawan & Komunikasi & Kerjasama & Kejujuran & Interpersonal & EIGEN PRIORITAS \\
\hline K1 & 0.08 & 0.08846154 & 0.0817121 & 0.08496732 & 0.475995316 \\
K2 & 0.106666667 & 0.07692308 & 0.1167315 & 0.117647059 & 0.270140515 \\
K3 & 0.093333333 & 0.09615385 & 0.0933852 & 0.08496732 & 0.158665105 \\
K4 & 0.08 & 0.09230769 & 0.0856031 & 0.091503268 & 0.095199063 \\
K5 & 0.097777778 & 0.1 & 0.1167315 & 0.107843137 & \\
K6 & 0.12 & 0.11538462 & 0.0933852 & 0.107843137 & \\
K7 & 0.088888889 & 0.08461538 & 0.0933852 & 0.091503268 & \\
K8 & 0.12 & 0.12307692 & 0.1167315 & 0.114379085 & \\
K9 & 0.097777778 & 0.1 & 0.1050584 & 0.094771242 & \\
K10 & 0.115555556 & 0.12307692 & 0.0972763 & 0.104575163 & \\
\hline
\end{tabular}

Tabel 14. Pemeringkatan Penilaian soft skill Karyawan

\begin{tabular}{ccc}
\hline KARYAWAN & NILAI & URUTAN \\
\hline K8 & 0.11954099 & 1 \\
K6 & 0.11317512 & 2 \\
K10 & 0.11311835 & 3 \\
K5 & 0.10255155 & 4 \\
K2 & 0.10245623 & 5 \\
K9 & 0.09911522 & 6 \\
K3 & 0.09301464 & 7 \\
K7 & 0.08889639 & 8 \\
K4 & 0.08523074 & 9 \\
K1 & 0.08290078 & 10 \\
\hline
\end{tabular}

a. Hasil Uji Validitas dan Reliabilitas

1) Uji Validitas

a) Kriteria Kompetensi Komunikasi

Validitas mempunyai arti sejauh mana

ketepatan dan kecermatan alat ukur dalam melakukan fungsi alat ukurnya.

Suatu kriteria dikatakan valid apabila kriteria tersebut mampu mencapai tujuan pengukuran dari kontrak amatan dengan tepat [15]. Suatu kriteria atau pernyataan dikatakan valid apabila p value (signifi'-nni hasil analisis) $\leq \leq$ taraf signifikansi $\left(\propto_{\propto}\right)$ 0,05 . Hasil uji validitas kriteria kemampuan komunikasi seperti terlihat pada tabel 6 .

Dari perhitungan yang tersaji di Tabel 6, diperoleh hasil $r$-hitung $=0,712$. Selanjutnya 
nilai tersebut dikonsultasikan dengan r-tabel product moment pada taraf signifikansi dengan $\mathrm{df}=8$, taraf signifikansi $5 \%=0,632$, dan taraf signifikansi $1 \%=0,765$. Jika $r$ hitung > r tabel taraf sig $1 \%>r$ tabel taraf sig 5\% maka dapat dinyatakan valid dan sebaliknya, perhitungan yang sama untuk semua item pertanyaan.

b) Kriteria Kompetensi Kerjasama

Nilai korelasi hasil uji validitas untuk kriteria kompetensi kerja sama seperti terlihat pada Tabel 7.

Dari perhitungan Tabel 7 diperoleh hasil r-hitung $=1.52$. Jika $\mathrm{r}$ hitung $>\mathrm{r}$ tabel taraf sig $1 \%>\mathrm{r}$ tabel taraf sig 5\% maka dapat dinyatakan valid dan sebaliknya, perhitungan yang sama untuk semua item pertanyaan.

c) Kriteria Kompetensi Kejujuran

Nilai korelasi hasil uji validitas untuk kriteria kompetensi kejujuran seperti terlihat pada tabel 8 .

Dari perhitungan Tabel 8 diperoleh hasil r-hitung $=1.565$. Jika $\mathrm{r}$ hitung $>\mathrm{r}$ tabel taraf sig $1 \%>\mathrm{r}$ tabel taraf sig 5\% maka dapat dinyatakan valid dan sebaliknya, perhitungan yang sama untuk semua item pertanyaan.

c. Kriteria Kompetensi Interpersonal

Nilai korelasi hasil uji validitas untuk kriteria kompetensi interpersonal seperti terlihat pada tabel 9.

Dari perhitungan Tabel 9, diperoleh hasil $\mathrm{r}$-hitung $=1.524$. Jika $\mathrm{r}$ hitung $>\mathrm{r}$ tabel taraf sig $1 \%>\mathrm{r}$ tabel taraf sig $5 \%$ maka dapat dinyatakan valid dan sebaliknya, perhitungan yang sama untuk semua item pertanyaan.

\section{2) Uji Reliabilitas}

Hasil uji reliabilitas.dapat diketahui dari nilai alpha cronbach's selengkapnya disajikan pada tabel 10.

Hasil uji reliabilitas menunjukkan bahwa nilai alpha cronbach's komunikasi 0.798 , kerja sama 0.987 , kejujuran 0.836 , dan interpersonal 0.604 . Karena nilai alpha cronbach's yang didapat masing-masing > 0.6. Hal ini membuktikan tiap variabel memiliki reliabilitas yang tinggi atau memiliki konsistensi yang baik sebagai alat ukur.

\section{b. Hasil Rekap Kuisioner}

Dari form kuisioner yang dibagikan ke karyawan, dapat dihitung skor untuk masing-masing kriteria untuk masingmasing karyawan. Hasilnya seperti terlihat pada tabel 11.

Tabel 11 menunjukan hasil rekap nilai dari masingmasing kriteria dengan skor yang dipakai, sebagai berikut: $1=$ Sangat Tidak Mampu

$2=$ Tidak Mampu

3= Cukup Mampu

$4=\mathrm{Mampu}$

$5=$ Sangat Mampu

\section{c. Matriks Perbandingan untuk Setiap Kriteria}

Hasil rekap dilakukan perhitungan matrikss perbandingan setiap karyawan untuk masing-masing kriteria, di bawah ini sebagai contoh hasil perhitungan matriks perbandingan pada kriteria kamunikasi seperti terlihat pada tabel 12 .

Contoh hasil perhitungan matriks perbandingan untuk kriteria komunikasi, dilakukan dengan cara membandingkan nilai masing-masing karyawan misalnya $\mathrm{K} 1$ nilainya 1 maka 1/1, K1/K2 maka 1/1.33, K1/K3 maka 1/1.16 semua kriteria dari semua karyawan,selanjutnya akan menghasilkan eigen masing-masing kriteria.

\section{d. Menetukan Prioritas/Pemeringkatan}

Untuk melakukan perhitungan prioritas atau pemeringkatan dari masing eigen setiap kriteria yang sudah didapat, seperti terlihat pada tabel 13.

Tabel 13 menunjukkan bahwa nilai prioritas untuk K1 diperoleh dari $(0.08 \times 0.475)+(0.08 \times 0.270)+(0.08$ x 0.158$)+(0.08 \times 0.095)=0.082$ dan seterusnya sampai dengan K10

Perhitungan matriks perbandingan semua kriteria dan nilai prioritas yang digunakan pada perusahaan menghasilkan pemeringkatan penilaian kompetensi soft skill karyawan, seperti terlihat pada tabel 14.

Tabel 14 menunjukan bahwa karyawan yang memenuhi kriteria sesuai kebutuhan perusahaan dalam penilian kompetensi soft skill dengan 3 prioritas tertinggi adalah K8 dengan nilai 0.11954 , K6 dengan nilai 0.11317 dan K10 dengan nilai 0.11311. Terdapat angka yang tidak sama pada angka ke 5 di belakang koma. Yaitu pada data K10 dan K5. Pada penelitian sebelumnya yang berjudul sistem pengambilan keputusan pemilihan karyawan terbaik menggunakan metode Analytic Hierarchy Process [4] belum menunjukan perbedaan yang jelas dalam penentuan prioritas karena masih terdapat data yang sama sampai digit ke 4 di belakang koma, yaitu pada peringkat ke 2 dan 3 dengan nilai sama-sama 0.1040 dan pada peringkat 6 dan 7 dengan nilai sama-sama 0.0980 .

\section{Kesimpulan}

Hasil penelitian yang dilakukan dapat diambil kesimpulan bahwa uji reliabilitas menunjukkan bahwa nilai alpha cronbach's komunikasi 0.798 , kerja sama 0.987 , kejujuran 0.836, dan interpersonal 0.604. Nilai alpha Cronbach's yang didapat masing-masing $>$ 0.6. Hal ini membuktikan tiap variabel memiliki reliabilitas yang tinggi atau memiliki konsistensi yang baik sebagai alat ukur. Pengambilan keputusan penilaian kompetensi soft skill karyawan dengan metode AHP menghasilkan nilai index consistency sebesar 0.05 artinya nilai kesalahan di bawah 5 $\%$. Sehingga nilai index konsistensinya benar dan dapat digunakan. Penelitian ini membuktikan bahwa metode AHP dapat digunakan dalam penilaian kompetensi soft skill karyawan sampai menentukan nilai prioritas karyawan tertinggi. Peneliti menyadari adanya ketidaksempurnaan dan saran yang dapat peneliti berikan untuk meningkatkan penelitian yang sama, yaitu dalam penentuan kriteria lebih banyak lagi dan juga menentukan subkriterianya, sehingga hasilnya akan lebih maksimal. Penelitian selanjutnya diharapkan melakukan pengujian dengan metode lain yang sejenis. 


\section{Daftar Pustaka}

[1] A. Rilman and A. Djamaris, "Analisis Faktor Kompetensi Soft Skills Mahasiswa yang Dibutuhkan Dunia Kerja Berdasarkan Persepsi Manajer dan HRD Perusahaan," J. Manaj., vol. 17, no. 2, pp. 160-174, 2013.

[2] A. Abdul Chamid and B. Surarso, "Implementasi Metode AHP dan Promethee untuk Pemilihan Supplier," J. Sist. Inf. Bisnis Mei, vol. 2, pp. 132015, 2015.

[3] N. Komalasari, "Sistem Pendukung Keputusan Kelaikan Terbang (SPK2T)," J. Ind. Elektro dan Penerbangan, vol. 4, no. 1, 2018.

[4] N. Palasara, "Sistem Pengambilan Keputusan Pemilihan Karyawan Terbaik Menggunakan Metode Analytic Hierarchy Process," vol. 4, no. 1, pp. 31-46, 2017.

[5] E. N. Sejati Purnomo, S. Widya Sihwi, and R. Anggrainingsih, "Analisis Perbandingan Menggunakan Metode AHP, TOPSIS, dan AHPTOPSIS dalam Studi Kasus Sistem Pendukung Keputusan Penerimaan Siswa Program Akselerasi," J. Teknol. Inf. ITSmart, vol. 2, no. 1, p. 16, 2016.

[6] S. D. H. Permana, "Sistem Penunjang Keputusan Pemilihan Sekolah Menengah Kejuruan Teknik Komputer dan Jaringan yang Terfavorit dengan Menggunakan Multi-Criteria Decision Making," J. Teknol. Inf. dan Ilmu Komput., vol. 2, no. 1, pp. 11-19, 2015.

[7] S. Utaminingsih, "Pengembangan Soft Skill Berbasis Karier pada SMK di Kota Semarang," Din. Pendidik., vol. 6, no. 2, pp. 119-133, 2016.

[8] R. Menggunakan, M. Confussion, S. Prodi, T. Elektro, F. Teknik, and U. T. Madura, "Simposium Nasional Teknologi Terapan (SNTT) 52017 ISSN: 2339-028X," pp. 267-271, 2017.
[9] H. Supriyono, "Pemilihan Rumah Tinggal Menggunakan Metode Weighted Product," Khazanah Inform. J. Ilmu Komput. dan Inform., vol. 1, no. 1, pp. 23-28, 2015.

[10] E. Lestari and E. U. Artha, "Sistem Pakar dengan Metode Dempster Shafer untuk Diagnosis Gangguan Layanan INDIHOME di PT TELKOM Magelang," Khazanah Inform. J. Ilmu Komput. dan Inform., vol. 3, no. 1, pp. 16-24, 2017.

[11] O. J. F. Wassalam, R. Umar, and A. Yudhana, "Implementasi dan Pengembangan Sistem E-Learning Berbasis Web pada STIMIK Muhammadiyah Paguyangan," in Proceeding SENDI, 2017, pp. 104-107.

[12] M. U. Manara, "Hard Skills dan Soft Skills pada Bagian Sumber Daya Manusia di Organisasi Industri," J. Psikol. Tabularasa, vol. 9, no. 1, pp. 37-47, 2014.

[13] A. Rokhayati, R. Kambara, and M. Ibrahim, "Pengaruh Soft Skill dan Perencanaan Karier terhadap Kinerja Karyawan dengan Kualitas Pelatihan Sebagai Variabel Modertor (Studi empiris pada PT. Krakatau Tirta Industri Cilegon)," J. Ris. Bisnis dan Manaj. Tirtayasa, vol. 1, no. 2, 2017.

[14] A. Nugroho and S. Hartati, "Sistem Pendukung Keputusan Berbasis AHP (Analytical Hierarchy Process) untuk Penentuan Kesesuaian Penggunaan Lahan (Studi Kasus: Kabupaten Semarang)," Sist. Pendukung Keputusan Berbas. Ahp (Analytical Hierarchy Process. Untuk Penentuan Kesesuaian Pengguna. Lahan (Studi, vol. 9, no. 2, pp. 1-14, 2012.

[15] Sugiyono, Metode Penelitian. Bandung: CV Alvabeta, 2000. 